\title{
The Economics of Khat Trade and its Dynamic Institutions: The Ethiopian Context since the 1980s
}

\begin{abstract}
Studies about khat have shown a remarkable progress in recent times, both in terms of quality and quantity. However, their focus to a large extent is on the chemistry and pharmacology of the plant; and more so on its impact on the consumers' health. The trading systems, the logic of the khat markets, the networks and the structures that kept the khat industry vibrant skipped the attention of researches. This study deals with the institutional evolution, performance and constraints of those institutions and structures governing khat trade in Ethiopia since the 1980s. A qualitative research method has been employed in this study. Yet, due to the complexity of the subject under study, I have to operate eclectically in my choice of data gathering instruments and analysis. Eclectically, in this context, refers to the application of divergent but complimentary methods of gathering, analysis and interpretation of data. Oral data for this study have been garnered primarily through key informant interviews and Focus Group Discussions (FGD).Oral data required for this study have been collected for over four years shuttling to both study sites in the east and southern Ethiopia on various field trips. Relevant secondary literatures dealing with khat have also been consulted. Findings from this research helped to document the evolution of some key features in the way the khat business is being run and the various work processes that consistently animated the trade. Attempts have also been made to shade some light on the institutional evolution of the trading system and the role of the state in khat trade in Ethiopia. I argue in this paper that decentralization and autonomy are the hallmarks of the prominent khat trading systems in Ethiopia.
\end{abstract}

Girma Negash*

Keywords: trade, Institutional economics, 'khat workshops', Kontrakter, Abba Safara

DOI: https://dx.doi.org/10.1314/ejossah.v16i1.4

\footnotetext{
*Associate professor, Department of History, Addis Ababa University, Email: girmanegnn@gmail.com, Tel: +251911434986, P.O. Box: 1176/ Addis Ababa
}

This work is licensed to the publisher under the Creative CommonsAttribution-NonCommercialNoDerivs License. 


\section{Girma Negash}

\section{Background}

This is a study in economic history focusing on the evolution and changes of institutions engaged in $\mathrm{khat}^{1}$ trade in Ethiopia. The principal objective of this undertaking is to document and analyze the origins and evolution of incrementally evolving institutions playing a key role in the business of khat trade and the various work processes that kept the khat industry in Ethiopia as vibrant as ever. By identifying key economic principles as well as evolution of institutions and structures functional in the two major khat assembling centers, Aweday and Wondo-Genet in East Hararge and in Northern Sidama respectively, the study intends to shed some light on the contours of the business of khat trade in the Ethiopian context.

The study borrows insights from what economists refer to as institutional economics and draws on some of their theoretical perspectives. Douglas C. North, a pioneer scholar attempting to bridge institutional economics and economic history provided a graphic description of what institutions are and what they are up to. He states:

Institutions are the humanly devised constraints that structure the political, economic and social interaction. They consist of both informal constraints (sanctions, taboos customs, traditions, and codes of conduct) and formal rules (constitutions, laws, property rights) ... They [intuitions] evolve incrementally connecting the past with the present and the future; history in consequence is largely a story of institutional evolution in which the historical performance of economies can only be understood as part of a sequential story (North, 1991, p. 97). ${ }^{2}$

\footnotetext{
${ }^{1}$ Khat, is an evergreen shrub widely grown and consumed in Ethiopia, Yemen, Kenya, Uganda, Malawi, Zimbabwe, South Africa, Madagascar and Zambia to name just a few countries. Studies suggest that khat leaves contain psychoactive substances capable of stimulating the central nervous system (Kenedy, 1987, pp. 183-187; Varisco, 2004, p. 104; Amare \& Krikorian, 1973, p. 375; Ward, \& Gatter, 2000, p. 40).

${ }^{2}$ Several scholars studied and wrote about institutional economics. The long quote from D. North is in no way an appeal to authority and intellectual legacy of the scholar alone. What makes the contribution of the Nobel laureate Douglass C. North, relevant and of special significance in this study is that he explains the role of institutions in economic development. More importantly, he argues that the study of their evolution across time, which he says is intrinsically incremental, is a key to connecting the past with the present.
} 
This particular research is inspired by two cogent drivers. Firstly, motivated by the imaginative insight outlined in the last part of the above quote, and armed with empirical data about progressively evolving institutions in the business of khat trade in Ethiopia, I am convinced of the possibility of doing an economic history anchored on the story of institutions and their development across time. Secondly, as succinctly explained by Professor North, despite the fact that weaknesses or strengths of institutions are good enough demonstration of the economic performance and efficiency of any given economy, they do not seem to get the attention they deserve in economic and historical analysis (North, 1991). Hoping to fill the lacuna in the study of institutions and institutional change, particularly in the khat literature, this paper explores the genesis and evolution, the efficiency and constraints of those institutions and structures put in place to expedite khat trade in Ethiopia.

The literature on instltutional economics ${ }^{3}$ demonstrates that institutions and particularly the story of their evolution do really matter in history. By showing the evolution and dynamics of local institutions while trying to respond to the needs of the time, and by enquiring into the role of local economic institutions in shaping the nature of economic performance, this study aims at making a substantive contribution to our understanding of the causal relationship between modifications, improvisations and restructuring of economic institutions at micro level; and the changes, evolution and development of economies up on which they are embedded. Overall, the two well established khat trading systems have been characterized by decentralized sets of relationships as well as elements of vertical and horizontal coordination in which efficiency was maintained among operators and/or traders at different levels.

Those issues to be exhaustively examined in this study include, among others, the crucial role of some key institutions in the system of khat-based transactions in the above-mentioned regions, the ways institutions I refer to as "khat workshops" "function, local wisdom used to handle "determinants of market

${ }^{3}$ I refer interested readers to see the works of North (1989) and Furubotn and Richter (2005), which clearly suggests that "institutional economics helps to improve understanding of economic history, and therefore plays an increasing role in modern economic history." (p. 45).

"I first coined the reference "khat workshops" and introduced it into the khat literature back in 2013 and 2014 while doing research for my $\mathrm{PhD}$ dissertation considering two important characteristics of a workshop which I personally observed to be functional in those khat wrapping houses. Firstly, a group/team of people working at one and the same place for one common end. Secondly, considering the wide range of important activities performed 


\section{Girma Negash}

perfection" such as efficiency and discipline. In this connection, the origins and nuances of two institutions in the trading structures of the east and southern Ethiopia; the Abba Safara and the Kontrakter respectively, are very much illuminating. Khat traders also operate in a rather risky and unsettled business environment, partly a reflection of the ambivalence of the public sector towards khat. This has entailed a structure of trade and trade relationships fraught with uncertainties and continuous renegotiation of the terms of engagement both among those in the trading chain as well as between them and a range of other people who have a stake in the business. In short, as in the production system, the trading system involving khat is still in a great deal of flux.

I argue in this paper that the khat economy in the Ethiopian context is not state-driven and less of a standardized economic undertaking. Decentralization and autonomy are the hallmarks of the two prominent khat trading systems in Ethiopia. The business of khat for a long time to date has been run by agglomeration of small local firms knitted together with a composition of local and to some extent foreign-based business groups. ${ }^{5}$ Reliance on market mechanisms, the rationale individual, the deregulated market, the profit maximizing entrepreneur are active forces shaping the modus operandi of the khat value chain in Ethiopia.

I will also show that khat trade in Ethiopia has been animated by vibrant, efficient and effective institutions and structures, largely of local origin. Most of these institutions (such as the "khat workshops", the Kontraktor-Aba Safara, and the practice of "whistle blowing") originated at different times and evolved through time adjusting and readjusting themselves to the requirements of khat trade.

My argument includes the point that the two khat trading systems have been characterized by decentralized sets of relationships as well as elements of vertical and horizontal coordination in which efficiency was maintained among operators and/or traders at different levels. Despite the fact that vertical networks have been unstable, trust rather than formal and legally valid contracts sustained khat transaction in east and southern Ethiopia.

in those workshops such as combining and recombining different varieties, assembling and reassembling of bundles of khat into retail sizes etc.

${ }^{5}$ In fact, some of the sharp contrasts in the two prominent trading systems operational in east and southern Ethiopia emanate from the very fact that one is meant largely for export trade, while the other one is entirely destined for the domestic market. 


\section{Methodology}

Due to the nature and complexity of the subject under study, I have to operate eclectically in my choice of data gathering instruments and analysis. Eclectically in this context refers to the application of different but complimentary methods of data gathering analysis and interpretation of data. In order to grapple with the complexities and nuances of the observed units and processes, the historical method which examines patterns, changes and continuities across time has been effectively used. Yet, in the broader sense, the study follows some basic guidelines of the qualitative method.

In my investigation of the economic performance of institutions over time, I benefitted from the insights and perspectives of institutional economics which specializes in the study of the evolution of institutions, and through them the development of local economies. In addition to that, I also used some important resources from the research methods of the social sciences, especially what they call the 'unit of analysis' - which is the major entity that is to be analyzed or studied. For example; individuals, groups, organizations, and even cases can be used as instrumental tools to study patterns, processes and changes (Garner et al., 2009, p. 172, \& Grunbaum, 2007, pp. 86-89). And most importantly, the units of analysis in this study are those institutions playing an irreplaceable role, and of course incrementally evolving, in the Ethiopian khat trade, albeit they remained the unknown 'black box' in the khat literature thus far.

Regarding sources, the evidence for this study is assembled from a variety of sources. In part due to the nature of the topic, and in part due to the poor state of documentation of government operations in Ethiopia, empirical evidence for this research is largely extracted from oral sources. Oral data used in this study have already been collected over the past three years shuttling to both study sites in the east and southern Ethiopia on various field trips. The data was collected through interviews, observation of the different work processes, and Focus Group Discussions with various participants operating along the different work processes. A typical FGD type of discussion the researcher had was the one held on 3 December 2015 with seven young members of the khat trading community in Chuko town (Wondo Genet) who were actively involved in the activities taking place in the "khat workshops," and other operations along the khat value chain. The researcher's familiarity with the issue under study as well as local people and local circumstances not only eased the rigor of field work but also helped to observe and analyse every activity closely and critically. My filed notes have been extensively used to fill some important gaps that might be lost through prolonged process of write up of the draft. Significant amount of information and theoretical 


\section{Girma Negash}

insights from secondary sources, chiefly from the academic area of institutional economics, have greatly enriched my understanding of the subject under investigation.

\section{The Locus: By way of contextualizing the material}

This section intends to provide both spatial and temporal details about the khat value chain, the khat markets under study and their historical origin. The two khat markets which are the focus of this study are the Tafara Market of Chukotown in Northern Sidama, (at the northern periphery of the Southern Nations, Nationalities and Peoples Regional State) and the Magala-Jima (khat market) of the town of Aweday, in Eastern Hararge, Oromia Regional State. The Tafara market is the largest khat market in northern Sidama. Along with Aweday in East Hararge, it is one of the two largest khat trading centres in the entire nation until about 2013/14. This southern khat terminus is found in Chuko town, formerly known as Basha town, located $30 \mathrm{kms}$. to the southeast of the town of Shashamane, and $272 \mathrm{kms}$. to the south of Addis Ababa. Following the administrative restructuring adopted in 2005 the town of Chuko became the administrative capital of Wondo GenetWoreda in Sidama Zone. The population of Chuko town according to reports of the Woreda Finance office in 2017 is estimated to be 8,900.

The year 1988 was a landmark in the emergence of the Tafara khat market in that same town. As regards to its present status and economic significance, Chuko town owes much to the vibrant khat trading activities at the Tafara market. The Tafara market is situated some six hundred meters from the main road that dissects the town of Chuko. It is only 7-8 minutes walking distance to the east of the road. Considering the quantity of khat daily transported out of the Tafara market, by about 2012, it was the largest khat market in southern Ethiopia. No other khat market in southern Ethiopia is ever known to deliver ten fully- loaded Isuzu trucks ${ }^{6}$ on average to various local towns every day. Observing the situation in 2005 and 2006 the authors of The Khat Controversy, described the Aweday market as "...the hub for the eastern Ethiopian khat trade," (Anderson et al., 2007, p. 45). At about the same time, and for over a decade now, the Tafara market seemed to have attained a similar position of importance for khat trade in southern Ethiopia.

The Tafara khat market is situated most importantly, surrounded by a large number of small houses (which I call "khat workshops") that proliferated surrounding the market that are built by private individuals. They are rented to khat

\footnotetext{
${ }^{6}$ Each Isuzu truck roughly carries up to three thousand Kilograms of khat at once. 80
} 
traders who need them to do all the packaging of khat before its departure to different destinations. In front of the main gate of the market place are several shops and tea rooms providing wide range of services to customers frequenting the market. In between my two fieldworks in the region from January 2012 to December 2015, the Tafara Market, had undergone tremendous change both in terms of its physical appearance and mechanisms of khat transaction. In 2013 the "Wondo Genet Khat Trading Share Company" was established. In consequence, the former trading system was reorganized around this company and the key role of individual entrepreneurs locally known as Kontrakters was weakened and dissolved ultimately. ${ }^{7}$ I personally observed in my visit to the region in 2015 that a renovation project at the Tafara market was well underway and had already cleared the widely scattered stalls in the former market place.

The Tafara Market used to have an innovative tradition that calls all khat traders to business at a fixed time. This was the tradition of "Whistle Blowing," that takes place every day at 6:00 a.m., to mark the official beginning of market operation. It was a local invention intended to avoid market anarchy and preemptive hustle and bustle that might affect orderly transaction. In my filed visit in December 2015 I also have confirmed that the tradition of "Whistle Blowing" is gone for good. Blowing a whistle by a person standing on a wreckage of stone wall to mark the beginning of market operations is no longer practiced.

Aweday, specifically its Magala-Jima, is the other major khat market centre in Ethiopia which I mentioned to have been 'the hub for the eastern Ethiopian khat trade' by the authors of The Khat Controversy. In fact, in the absence of any other serious contender, it has remained in that capacity to this day. The town of Aweday, in Eastern Hararge, Oromia Regional State is located $9.35^{\circ}$ latitude north, and $42.05^{\circ}$ longitude east. It is only $12 \mathrm{kms}$. to the south-west of the historic town of Harar, and $500 \mathrm{kms}$. to the east of Addis Ababa. It is situated 6680 feet above sea level and has a Woinadega (temperate) climate. The population of Aweday in 2007 was estimated to be over 48,680. ${ }^{8}$ The town of Aweday and its Magala-Jima are the nexus for multitudes of khat traders from diverse ethnic and religious backgrounds, swarming from mid-day all the way through to day break. Here, the various forms of social interactions among the people of the town and the shuttling traders and all the rest daily activities are, to a large extent, shaped by khat and khat trade. As far as khat trading activities are concerned, it is difficult to draw a

\footnotetext{
${ }^{7}$ Interview with Zerfu Saqalo 19 Nov. 2015

${ }^{8} \mathrm{~A}$ brochure that bears a call for investment, released by the city Administration of Aweday in 2015
} 


\section{Girma Negash}

clear- cut border line between the khat market (the Magala-Jima), per se and the town at large. Although the Magala-Jima has the largest concentration of khat wrapping houses and is the centre for other khat-related institutions, it would be an impossibility to find out a "khat-free zone" in the entire town of Aweday. One can hardly find any location in the town of Aweday where khat transaction doesn't take place. This in part is the reason why many people refer to Aweday itself as just a khat market than a town in its own right.

The town of Aweday was founded sometime around 1947. Historically, the site where the present town of Aweday is located had been a small village known as Diddimtu (which literally means "the reds"). Initially, khat trade in Aweday was a disorganized road-side business without a specific centre at a specific place. It was not a full-time enterprise where professional khat traders were engaged in khat trade exclusively. The establishment of the Magala-Jima, in 1973, with stalls for the marketers to stay at, and make price negotiations, was a major watershed that brought some degree of order to khat trade.

According to Aweday City Administration, by 2015, some 60,000-80,000 kilograms of khat was brought to the khat market at Aweday every day carried by a variety of means of transport, chiefly Isuzu trucks. Presently, khat trade is a means of livelihood for more than half of the population of the town whose lives are connected to khat trade in one or the other way. Some 8,000 khat farmers, women and men alike, are regular visitors of the town to sell their khat bundles. Owing to the vibrant khat trading activities the daily capital turnover of Aweday town was estimated to be around 10 million birr by about $2015 .{ }^{10}$ Khat trade has been the reason for Aweday to earn the epithet "the only town in Ethiopia where the sun never sets." The ever-thriving khat industry is also the reason for the presence of a 24 hours- round banking service in Aweday town, the only of its kind in the entire region.

\section{Khat markets and key institutions they begot}

If it is to understand the nature, origins and evolution of institutions and organizations/associations actively involved along the khat supply chain, it would be of paramount significance to identify key institutions which I use here as unit of analysis, and probe into the manner of their operation, especially their evolution

\footnotetext{
${ }^{9}$ A brochure by Aweday Town Administration, 2014

${ }^{10} \mathrm{~A}$ brochure that bears a call for investment, released by the city Administration of Aweday in 2015
} 
and ways of adjusting themselves to the requirements of a competitive market. ${ }^{\text {II }}$ The rationale is that this would allow us to appreciate the ingenuity of local knowledge and the collaborative efforts of the trading community to discharge their duty (the smooth flow of khat transaction) and doing it with at most efficiency. In pursuance of this objective here below I will probe into the story of two contemporaneous institutions simultaneously operational, both at Tafara market (Chuko town) and Magala-Jima (Aweday), successfully facilitating the smooth functioning of the khat value chain. The trading systems at work both at Chuko town and Aweday share many similarities. Therefore, I will show the degree of resemblance when they appear to be similar and provide a comparative analysis when there are distinct differences in the manners khat transactions were being run, the nuances of some of the basic rules and regulations with a binding force on the trading chain.

The first of these two entities, or institutions, selected as a unit of analysis to be examined and discussed here are the Kontrakter of the Tafara market and the Aba Safara of the Magala-Jima. The stories of their origin, evolution and function epitomize the historical process how khat trade in Ethiopia was a truly decentralized process creating endogenous institutions and structures to regulate khat transaction when necessary. The Kontrakter who plays the role of a middleman and a transporter in the Sidama khat trading system, commanded an important place in the trading structures and can justifiably be considered as an institution. The service this institution rendered to the khat business in the 1990s had been a relatively new introduction into the Sidama khat trading operations. It was an institution in the sense that more than a dozen people are working as a team for one common goal under one boss and owner, the Kontrakter. The Kontrakter, as a person is the owner of the business, the owner of all the capital invested, and the manager who leads and supervises the entire operation. This institution draws its origin from the challenges of the daily routine of the khat business particularly irregular and unstable tax regimes, and refined further through repetitive application (Girma, 2017, p. 10).

The emergence of the Kontrakter as an institution could be traced back to the year 1992 when three well known khat traders in Chuko town started to

11 The following statement from the writings of an economist, Douglass North, is inspirational and bequeaths a meaning to this work. "It is the interaction between Institutions and organizations that shape the institutional evolution of an economy. If institutions [such as regulations, codes of conduct] are the rules of the game organizations are the players" (North, 1994, p. 361). 


\section{Girma Negash}

facilitate the process of khat transportation to different destinations. The special significance of the service those three individual traders rendered to their associates lies in facilitating a very efficient and time-saving tax payment. It is to be recalled that this particular period was a time of transition from the derg to the EPRDF-led government. Owing to a relatively weak central government and administrative laxity in the regions, there had emerged several custom posts along the khat route to major khat receiving towns. Custom places at short intervals, for example, at Kella-Bussa-Shashamane-Kuyara (Kella)-Mojo, and later at the Qaliti customs post hindered the smooth flow of khat transaction and the timely delivery of the commodity to the urban retailers. It was these inconveniences that led to the very inception of the institution of the Kontrakter. In two / or three year time the institution evolved to become an effective agency ensuring custom payments at one or two places only, and the delivery of khat to the various urban centers at the shortest possible time. ${ }^{12}$

Frist and foremost, the institution of the Kontrakter helped to avoid a sort of per-head tax payment in which every individual trader should appear in person to account for the quantity of khat at his disposal and negotiate the amount of payment required of him. The innovation the Kontrakter has placed the responsibility of tax payment in the hands of one person, later to evolve as an institution. Individual traders themselves, not the government or any of its local agencies, took the lead to fix the problem by inventing such a mechanism. Assigned tax collectors at the different custom posts welcomed it because they found the new arrangement helpful in discharging their duty. People involved in the khat business were well aware of the tax obligations that their engagement entail. What was of grave concern for the khat business and the traders was the possible delays that might arise in the process of tax payments at the chain of custom posts (Girma, 2017, p. 213). The reason is simple. Once again, it is because such delays would hamper the timely delivery of the khat. In any case, the fact that the Kontrakter is in charge of tax payment at custom places, representing the body of traders, is suggestive that the authenticity of the institution has got a measure of recognition outside the community of traders as well.

The other major responsibility of a Kontrakter is to provide a dependable transport service on regular basis. The most ideal means of transport used were Isuzu trucks. Most of the Kontrakters have their own Isuzu trucks. One can run the

\footnotetext{
${ }^{12}$ Interview with Samuel Dukamo 29 December 2011; Interview with Orrissa Hose 27 January 2014. Incidentally, these had been two of the three individual khat traders who first experimented to play the role of a Kontrakter back in the early 1990s.
} 
business by using hired Isuzu trucks. The difference is that the amount of profit a Kontrakter working with rented trucks generates was lesser than those who run the business with their own trucks. ${ }^{13}$

The Kontrakter, as a person, owns the capital and all other assets of the business, and is the de facto manager. Except on occasions of forced absence, Kontrakters rarely delegate their tax-paying role to a subordinate. Carrying the cash envelops from the retailers in different towns back to the khat assembling centers that same day is also the responsibility of the Kontrakter. He does the tax payments and cover the transportation expenses with his own money which he later collects, his profit included, when the envelops are distributed to the respective "Agent-Purchasers." The weight of each bundle had already been measured the other night. It will be checked with the money in each of the envelops and the Kontrakter's share will be deducted from the total. There are 5-8 persons on the payroll of the Kontrakter for loading and unloading khat bundles. At least two of them are part of the shuttling crew to do the unloading at different delivery points. In general, a successful Kontrakter needs to be extremely versatile ready to fill any gap in the whole course of the business operation. ${ }^{14}$

In sharp contrast with the institution of the Kontrakter operating at the Tafara market comes the role of the institution of the Abba Safara at the Aweday khat market. The exact beginning of Abba Safara operating as facilitators of khat trade is difficult to tell. Some accounts tell that the roots of the institution may go as far back as the very early days of the establishment of the town of Aweday and subsequently its Magala-Jima sometime around the eve of the Ethiopian revolution. Informants recount that around 1975, just a year after the outbreak of the revolution, two individual khat traders of Somali descent started to purchase large quantities of khat from Aweday for Dire-Dawa market, possibly for export to Djibouti and Somalia. They were called Lungo and Bureye. They had local agents named Adem Yuye, Umer Ahmed and Adem Aliyu. The latter three, were just bridges connecting several other khat collectors at Aweday market and the two Somali khat traders. It was those who collect several bundles of khat from khat farmers and supply it to the three agents of the Somali traders gradually evolved to become Abba Safara. They continued to supply khat to whoever came to the Aweday market to purchase large quantities of khat to be shipped out of the town

\footnotetext{
${ }^{13}$ Interview with Legamo Ledamo (Khat Trader), 4 December 2015; Interview with Zerfu Saqalo ( a former kontrakter) 19 November 2015

${ }^{14}$ Interview with Zerfu Saqalo, 19 November 2015
} 


\section{Girma Negash}

ever since. ${ }^{15}$

Etymologically the name Abba Safara is the product of two combined words. The first word Abba is a word from Afan Oromo (the language of the Oromo) which literally means 'father,' but in this context refers to owner, or the person in charge. Whereas the word Safara refers to the business in its entirety, or the location, or rather simply the whole institution under the auspices of the $A b b a$ Safara. Nevertheless, a more concrete story showing the Abba Safara playing a key role in the khat business operations as an institution points to the 1990s when Aweday started to outshine rival markets in the region as a hub for export trade. ${ }^{16}$

The number of assistants to the Abba Safara, locally known as the Geffeta, may vary from ten to twenty-five, as per the capital of the business and the number of clients the Abba Safara has. Similarly the number of client-suppliers each Abba Safara has may vary from two hundred to three hundred each, again depending up on his capital and the size of his business in general. The Geffeta, are usually young boys ${ }^{17}$ in their teens who set out to the Magala-Jima and all the entrances heading to the market place in order to fetch all the khat brought to their respective boss, or their Abba Safara by several client-suppliers. The major job of the Geffeta is bringing as many khat suppliers and khat bundles as possible to their respective Abba Safara in return for a commission payment from the trader. What made the service of the Geffeta more desirable to the Abba Safara is that most of them are able to finish the lobbying and the price negotiations on their own and reduce the burden of the boss. ${ }^{18}$

In contrast to the practice at Aweday, one who purchases large quantities of khat and the manager of the "khat workshops" of the Tafara market is the one whom I called "Agent-Purchaser". He often works in partnership with more than two or three retailers in Addis or other urban centers. Most, if not all, "AgentPurchasers" reside, with or without their families, in the town where the major khat

\footnotetext{
${ }^{15}$ Interview with Nuredin Abdulmalik and Abdulhamid Majid, 15 September 2018

16 Interview with Abdulhamid Majid, 12 February 2016; Interview with Abdulhakim Abdulahi, 14 February 2016

${ }^{17}$ The vigorous participation of children, sometimes as young as eight years old, in khat trading activities in the above-mentioned khat marketing centers, has been thoroughly discussed in a recent FSS publication. I defer those who are interested in the details to see FSS Monograph No. 13, 2017.
}

${ }^{18}$ Interview with Abdulhamid Majid, 12 February 2016 
assembling center is situated. Chief among their job is purchasing khat from the market and preparing standard zurbas (smaller units ready for sell) through the process of combining and recombining of packages made at the first round on the khat farm itself. He is the one who organizes the entire work process and pay for the work force deployed in the "khat workshops". Crew members at the disposal of a single "Agent-Purchaser" may vary from one purchaser to the other. In most cases they consist of five to eight persons, mostly boys in their teens. "AgentPurchasers" operating at the Tafara market have assistants helping them in the course of the purchase and in the wrapping process in that "khat workshops." These assistants need to be versatile because their assignments were diverse. Their service is required both at the market place and in the "khat workshops." At the market place, they help the "Agent-Purchaser" in selecting a khat of better quality and make preliminary deals swaying the seller before other competitors intervene. Their knowledge of the local language, which some of the "Agent-Purchasers" lack, is also a vital asset effectively exploited in the course of price negotiations. ${ }^{19}$

The role of the Abba Safara in the khat trading system at work in Aweday is somehow intriguing. One can hardly call him, a manager or owner of the business as in the case of the Kontrakter. By the same token, it is not uncommon to come across some Abba Safara who lay some amount of capital in the khat business and go beyond the conventional role of the Abba Safara. It sounds reasonable to refer to the Aba Safara as middleman in the khat transaction that connects the two ends of the khat value chain, that is the khat farmer (or sometimes khat suppliers who fetches khat to the Magala-Jima from nearby farms), and the khat traders, sometimes khat exporting unions and at other times khat exporting companies. ${ }^{20}$ In this sense, the Abba Safara and the business or the institution he is leading, resembles with the role and responsibilities of the Kontrakter in that he makes life easier to both khat farmers/traders. Those distinct tasks of the Kontrakter at the

${ }^{19}$ Interview with Zerfu Saqalo, 19 November 2015; Interview with Legamo Ledamo, 4 December 2015

20 "Companies," unlike the Abba Safara, are distinct groups or assortment of khat exporters with big capital who often run their business in hard currency. This is a very unstable unit in the khat trading structure, an area very much competitive and changing characters in their ways of operation and organizational structure. At times some might operate individually and at times as an organized unit, call it a company or a union. They have the ability to change their shape as the trading environment requires. Owing to this frequently changing style of existence and operation, I could not consider them as an institution and treat them in this discussion as such. 


\section{Girma Negash}

Tafara market such as facilitating transportation and tax payments at customs posts were not the worries of the Abba Safara at Aweday.

Another remarkable resemblance between the Abba Safara and the Kontrakter is the value of trust which in fact has always been characteristic to the business of khat trade at least in the Eastern and southern Ethiopia context. It appears that the possible void that the absence of structured and centralized networks might have created on the business of khat trade has been filled by institutions such as the Kontrakter and the Abba Safara. Unlike the Niambane miraa [the Kenyan name for khat] trade in which kinship, sometimes marriage relations are vital for trading cooperation and safety/security, ${ }^{21}$ here the trade is reinforced by mutual trust among actors at different levels and the reputation and trustworthiness of the Kontrakter and the Abba Safara have built among the community for years.

In the 1990s, at the Tafara market, a contractual approach to facilitate a vertical inter-firm coordination in khat trading activities was introduced. Contracts between the urban retailers and the local purchasers had been so loose and trust was a vital ingredient to the enforcement of the agreement rather than any written and legally valid document. In fact, the initial capital to be used as a seed money in subsequent transactions, originally belonged to the urban-based trader. That same money had been moving back and forth between the two ends of the supply chain via the envelope system. Interestingly, the two parties might not have the opportunity to meet physically. Only the coming of cell phones brought about the opportunity to make verbal conversations and enter into an oral agreement, which still is very loose and less binding in front of the law. The only guarantee, therefore, remained to be trust and the desire of both parties to stay active in the trading activities. ${ }^{22}$

The building of trust and credibility is very vital to cultivate and nourish future business relationships especially with clients who regularly supply khat to the market. Treating clients, who bring khat bundles to the Magala-Jima with the utmost courteousy and kindness, have always been the assets of a successful $A b a$ Safara. The courteous reception starts right at arrival to the Abba Safara's place

21 According to Neil Carrier there are other more important elements decisive for the smooth functioning of the Kenyan miraa trade networks other than trust. He states the key role of such elements as kinship relations, intermarriage, friendship, and even what he calls "supporting factors" which are sought by traders so as to preclude deception and minimize other risks (Carrier, 2007, p. 159-163).

${ }^{22}$ Interview with Zerfu Saqalo, 19 November 2015; Interview with Tesfahun Tadele (young worker in a "khat workshop"), 2 December 2015 
/stall by supplying soft drinks, bottled water, and khat for chewing there and then. The rest of the transaction process is left to the ingenuity of the Abba Safara. He would negotiate the price of each kilogram of khat which may vary from day to day. Interestingly, the farmer/ or supplier and the trader-transporter never meet physically let alone negotiate the terms of the transaction. As a matter of convention, the suppliers put their entire faith on the Abba Safara and they never check, or ask, the day's price (which is a subject of constant fluctuation), the overall weight of the commodity they brought, and how their share has been calculated, from any one. Often, they will be told about the terms of the deal by their respective Abba Safara when they finally collect their money. This is how it worked for over three decades. Even these days, where mobile phones are found in almost every khat farmer's household the old rules still work and farmers do not ask to know the day's price before the deal is done. One of the Abba Safara I interviewed ${ }^{23}$ claims that they deserve that level of trust from suppliers because they take it their responsibility to negotiate for the price with all honesty on behalf of their clients and ultimately take their share of the money by deducting from the paid amount with the rate of ten birr out of every hundred, which amounts to ten percent of the bargain. ${ }^{24}$

In a similar fashion, at the Tafara market, I have not heard, or seen anything about a written agreement at any level of the trading chain throughout my stay in the field which I was able to confirm to be true through oral testimonies of khat traders. A detailed examination of the modus operandi of the trading system at work demonstrates that the Kontrakter for all practical purposes stands as a dependable insurer of the whole exercise. As a matter of practice, he is to be held accountable in any event of damage on the commodity after he received it, or any kind of delay on delivery. There is no formal legal contract between the "Agentpurchaser" who purchases khat from the local market and send it to retailer in the towns. Some might enter oral commitments through the intermediary role of one or the other Kontrakter. Credit to the expansion of the cell phone in recent times, all that the two sides need is a simple telephone conversation and establish a mutual understanding and trust upon which the informal contract hinges. ${ }^{25}$

${ }^{23}$ Interview with Abdulhamid Majid, 12 February 2016

${ }^{24}$ I have been told that this was the rule regarding the rate of the Abba Safara 'commission' at least for the last five years now (interview with Abdulhamid Majid, 12 February 2016).

${ }^{25}$ Interview with Sabit Jamal (khat trader), 3 December 2015; Interview with Zerfu Saqalo, 19 November 2015 


\section{Girma Negash}

\section{The "envelope system"}

It sounds relevant to bring the other major hallmark of the Sidama khat trade, which I call the "envelope system" to the lime light here. Any discussion about the Kontrakter as an institution would be incomplete if it skips to mention a locally invented mechanism of money transfer called here the "Envelope System." Why I have to bring the issue of the "Envelope System" to the attention of the reader at this juncture is because trust is instrumental that sustained the proper functioning of the "Envelope System." Secondly, in a short and precise language, it significantly facilitated the business of khat trade in the Sidama context.

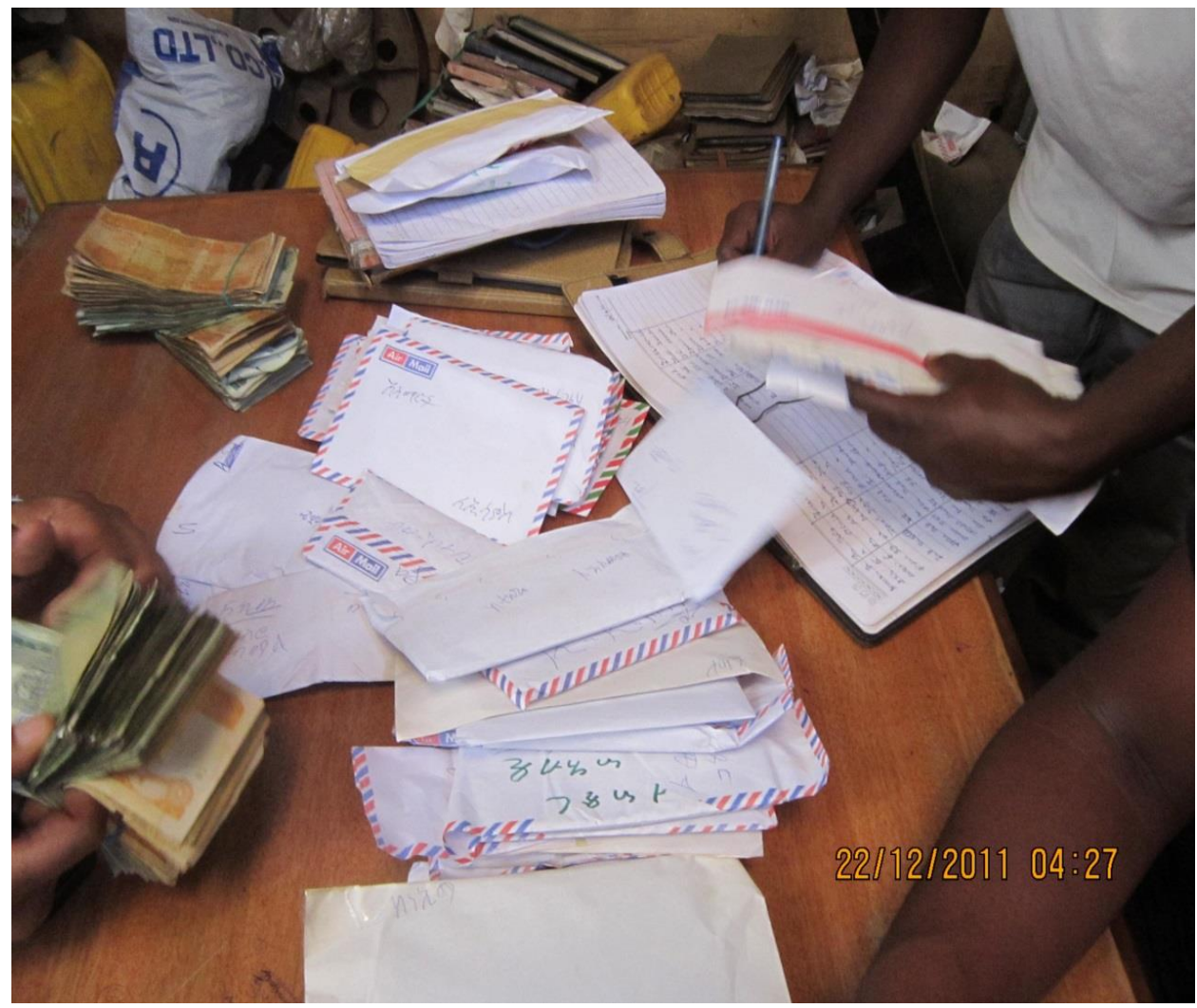

Figure 1: Cash envelops: Outside this small room, large number of "AgentPurchasers" are waiting anxiously. 
The "envelop system" is a unique approach in which price money for a given quantity of khat an urban retailer received will be transferred to the local purchaser on the other end in the hands of the Kontrakter who fetched the khat bundles. As mentioned earlier, the Kontrakter plays a key role in the management and execution of the "envelop system." For that matter one can even say that it was the trust and recognition the institution of the Kontrakter hold that helped the smooth operation of the khat business in those years. Reciprocally, the smooth operation and perpetuation of khat transaction made the service of the Kontrakter invaluable and irreplaceable for a long time. ${ }^{26}$ Who exactly devised this system originally is difficult to tell. Nevertheless, it has continued to serve the purpose it was designed for effectively. The people in the business seem to be comfortable with it, especially as far as trust and safety is concerned.

An objective proof to the credibility that the "envelope system" was able to foster during the life time of the institution of the Kontrakter could be sought in the evident fact that the service of banks had been unwelcome, at least up until 2012, among khat traders operating at the Tafara market and Chuko town. Normally, banks are the most efficient and safest means of money transfer. The "envelop system," which I consider as a unique symbol of the Sidama khat trade, had remained the sole mode of money transfer between the urban retailers and their local khat purchasers, at least up until 2012 and 2013. The commercial Bank of Ethiopia has opened its branch at Chuko town since 8 June 2010; however, it was not that popular even three years later. ${ }^{27}$

${ }^{26}$ Interview with Sabit Jamal (khat trader), 3 December 2015; Interview with Zerfu Saqalo, 1 November 2015

27 Interview with Sabit Jamal \& Zerfu Saqalo, 1 November 2015; why the wider community of khat traders have faithfully stuck to the envelop system for a long time is more complex than it may appear on the surface. One of the reasons, as pointed out by traders, was efficiency and persistence. Traders at the supplying end were content with the regular and timely delivery of the pay for the khat bundles they just sent the day before. Secondly, traders and brokers complained that it is common to sit in the banks in those days for long hours and in the end being told that their money has not reached the bank yet. The third reason for khat traders to stick to the "envelop system" at the expense of bank-based money transfer was the question of holidays. The khat business doesn't know religious or National holidays. The towns should be supplied by khat regularly. On the contrary, banks observe these holidays and it is a day off for their staff. See Girma, (2014). 


\section{Girma Negash}

\section{"Khat workshops"}

The existence of "khat workshops" and their pivotal role in the khat business both at Aweday and Chuko town is relevant and worth discussing here. By way of introduction, it could be said that "khat workshops" are small and big tin-roofed houses, sometimes hats and sometimes rooms situated on three or four story buildings as in the case of Aweday. They are, in large measure, located by the side of the khat market, or not far from it. There had been two hundred fifty to three hundred of them at the Tafara market at the time of my filed work in 2011, 2012 and 2013, and more than fifteen old and newly built buildings with rooms set exclusively for this purpose, without mentioning the small mud houses scattered throughout the town of Aweday by 2015 and 2016. In 2015 the number of "khat workshops" in Aweday town was reported to have reached a little more than four hundred. Most of the "khat workshops" are situated closer to the khat market itself, except in some cases as in Aweday. The majority of them were built by their owners who might not be in the khat business themselves but sought to get income by renting them. ${ }^{28}$ In sharp contrast with their counterparts at the Tafara market, most of the "khat workshops" at Aweday, probably since 2013 and 2014, are situated in big buildings, as high as ground- plus- four and sometimes groundplus- five.

${ }^{28}$ Interview with Abdulhamid Majid, 12 February 2016; Interview with Abdulhakim Abdulahi, 14 February 2016 


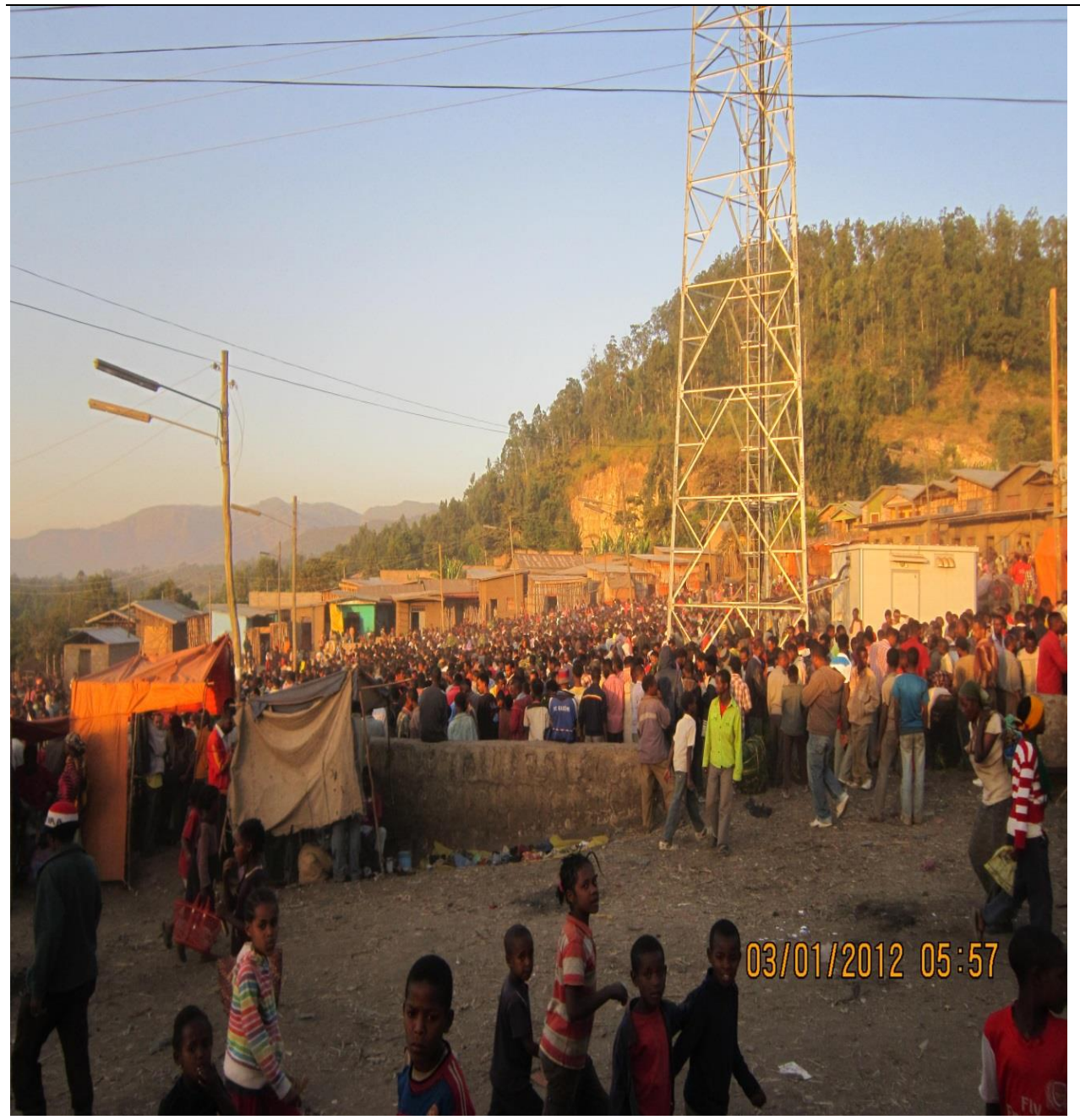

Figure 2: The Tafara Market (in 2012) surrounded by "khat workshops"

Over fifty per cent of the rooms on those big buildings, which stand as iconic symbols of the town of Aweday at present, are rented to provide the service of "khat workshops," as described below. A straightforward and understandable reason for this marked distinction between the "khat workshops" in the two market centers is none other than the fact that Hararge's khat has increasingly become a "dollar leaf." This means the lucrative income from khat trade made the Aba 


\section{Girma Negash}

Safara $^{29}$ and other traders and transporters capable of paying expensive rents. In fact, it was the relatively successful ones with elaborate network of connections who can afford to rent workshops on those buildings. Others would be forced to do business in small tin roofed rooms and, at times, even in their own homes. Year after year owners of those buildings are encouraged to invest more anticipating a mouthwatering return upon finishing construction. ${ }^{30}$

The simplest definition of "khat workshops" would be khat wrapping places.

However, only on the surface "khat workshops" are khat wrapping houses. They rather hold a very critical place in the marketing system both at Aweday and Chuko, and their role is more profound than that. They are platforms where most decisive operations of "aggregation" and "reaggregation," "combination" and "recombination"31 of different varieties, and standardization, with all their implications on the price takes place. It is under the roofs of this small houses that the art of "playing with form" is practiced with cunning hands well intended to manipulate value.

As widely known among the khat trading community in Aweday, the job process concerned with the preparation of smaller saleable units is alternatively known as Zefa or Shelala. As at Tafara market, this very critical work of a very indispensible economic value has been a regular routine performed every night in the "khat workshops." The major task for all persons engaged in this work is categorizing khat types according to their quality and prepare standard units with varying weights and price tags such as 200 birr, 300 birr, 500 birr 1000 birr etc. ${ }^{32}$ According to my own observation khat bundles actually spend only few hours in those workshops. That was the moment when different varieties of khat are being mixed together to form different categories of retail units. The ingenuity in this exercise of "playing with form" lies in aggregation and reaggregation of inferior quality khat, obviously bought for cheaper prices, with better quality and relatively more expensive khat wraps.

This exercise of mixing inferior quality khat with high quality khat in the "khat workshops" of Aweday for the purpose of manipulating value is commonly

29 Interview with Abdulhamid Majid, 12 February 2016 \& Abdulhakim Abdulahi, 14 February 2016; the Aba Safara use some of the rented rooms, often neighbored by "khat workshop," for use at day time as thier office and reception room for their clients and their khat bundles until the deal is done.

${ }^{30}$ Interview with Abdulhakim Abdulahi, 14 February 2016

${ }^{31}$ I have borrowed these terms from Neil Carrier who has contributed a comprehensive account of Kenyan khat trade back in 2007. See Neil Carrier (2007).

${ }^{32}$ Interview with Hassen Ahmed (khat trader), 11 February 2016; Interview with Abdulhamid Majid, 12 February 2016

94 
known as Walqabbanessaa which literally means "cooling down." According to informants, the principal motive behind the Walqabbanessaa which is all about the combination and recombination of khat varieties, by mixing little amount of high quality khat with larger amount of poor quality khat, is none other than raising the value of the aggregated unit and thereby maximizing profit. ${ }^{33}$

The process carried out under the roofs of those houses is more subtle and complex. Packaging is an essential and final process of commodity transaction including khat trade. ${ }^{34}$ What is unique about packaging as performed in the "khat workshops" of Aweday and Chuko town is that it is not done for the purpose of beautifying, or adding color and good look to an article as is the case in the packaging of most other factory products. Here packaging is a process performed with sophistication and care intended to add to the economic worth of the substance. Neil Carrier, in his study about khat trade in Kenya, explains packaging as a process that involves combination and recombination of different sizes and different qualities of khat as an innovative and entrepreneurial act well intended to maximize profit. In the words of Neil Carrier, "Throughout the network one sees Miraa [the Kenyan name for khat] being aggregated into bundles to be disaggregated later and retied in a different-more profitable-formulation. This playing with form is seen in both the national and international trade...." 35

The large majority of the crew members working the whole night in the "khat workshops" both at Aweday and Chuko town are youth in their teens. ${ }^{36}$ They are engaged in this daily routine characteristic to those "khat workshops." Only the better skilled and experienced children connected to traders might get access to this job. As stated above, these young persons are engaged not simply in wrapping and packaging of khat bundles, rather in aggregation and reaggregation; combination and recombination of different varieties of khat brought to the khat market from various sources. This is a very important work process both for the traders and the children involved. For the traders, this work process is important because it is here extra profit could be obtained without adding any substantive value, just by

\footnotetext{
${ }^{33}$ Interview with Hassan Ahmed, 11 February 2016; Interview with Abdulhamid Majid, 12 February 2016

34 For example, the Baher-Dar khat which is getting a growing popularity among the khat consumers of Addis Ababa and nearby towns is served by plastic bags unlike the tradition that used to pack or wrap khat from other khat supplying regions.

${ }^{35}$ Carrier (2006) article is committed to analyzing the process of packaging and its role in the creation and manipulation of value in the Kenyan khat trade.

${ }^{36}$ See Girma (2017), FSS Monograph No. 13.
} 
Girma Negash

combining and recombining the same stuff. For the children, it is highly rewarding by the standards of other children engaged in carrying khat bundles and do the cleaning of the workshops for a very low pay.

\section{Determinants of market perfection in the Ethiopian khat trading systems}

This section attempts to untangle the mysteries as how the khat marketing systems operational in East and south Ethiopia have been able to cope up with the requirements of a business operation in a modern setting. Determinants of market perfection refer to those variables directly or indirectly affect the smooth functioning and efficiency of a trade, or a distribution system of a given commodity or product. They include, among others; “... too many intermediaries, a long chain of middlemen [that unnecessarily raise the marketing cost], inadequate infrastructure, barriers to entry, exploitative pricing practices by middlemen, and excessive variability in quality and quantity of supply" (Eicher $\&$ Baker, 1982, p. 184.). The purpose of efficiency analysis here is largely meant to provide insights as how a deregulated and decentralized trade as the business of khat trade in Ethiopia has managed to be consistently efficient and productive.

More tantalizing is the fact that some fundamental guidelines of the business under discussion here are not so much drawn from a state of the art business management methods and strategies but rather from the special nature of the commodity, and some of its concomitant requirements, largely animated by the ingenuity of local knowledge and feedbacks from the actual exercise. Most of the local institutions discussed so far; such as the "khat workshops," the institutions of the Kontrakter and the Aba Safara, the practice of "whistle blowing," especially at the Tafara market, ${ }^{37}$ and most other improvisations introduced in order to facilitate efficient and effective system of khat transportation and delivery, originated at different times and evolved through time adjusting and readjusting themselves to the requirements of khat trade, have been of local origin. None of these are the gift of an exogenous wisdom drawn from more sophisticated and state of the art business management methods and techniques.

First and foremost, it should be underlined that efficiency and consistency

\footnotetext{
${ }^{37}$ This tradition was somewhat a daily ritual practiced at the Tafara market in the 1990s calling for the beginning of the actual khat transaction at a uniform time. It was aimed at centralizing the time for khat buying at the Tafara market. In those days the practice allowed traders to have sufficient time for packaging, and then the departure of the khatloaded trucks in good time. See Girma, (2014, pp. 256-257).
} 
have always been pivotal to a khat trading business defining the success or failure of the whole enterprise. Broadly speaking, this is not unique to khat trade in the Ethiopian context. Efficient marketing and delivery systems have almost become universal hallmarks intrinsic to the khat industry and a khat value chain where ever it operates on African soil. For example, Paul Goldsmith underlines that khat trade in Kenya is "remarkably efficient" governed by a system that hinges upon local knowledge. He claims that the business of khat trade in Kenya greatly benefited from the absence of government intervention. He concluded that the absence of government intervention was a blessing than a curse for the khat business. A show case he used to reinforce his argument was the case of khat trade in Tanzania where inefficient and corrupt state apparatus of the socialist government and its overly centralized system crippled both production and trade (Goldsmith, 1988, p. 146).

By modest standards, khat trading systems in Northern Sidama and Aweday, to my judgment, are still efficient and vibrant, operating effectively, a livelihood base to many people, and generating substantive revenue for the government as well. Trading chains, reasonably autonomous, decentralized but interlinked to one another through mutual trust are effectively functioning. The most important reason for efficiency to be an essential requirement in khat trade relates to the very nature of khat being a perishable commodity with a shelf life of 48 hours. Because of this particular physical property of khat, an efficient trading system and expeditious delivery are crucial prerequisites for the survival of a khat business and a khat trader. Khat leaves would maintain their potency if they are used within 48 hours of cut. Therefore, khat has to be marketed quickly in order to avoid wastage. Customers in town do not tolerate any delay in the daily provision of khat. That is why a high level of discipline and consistency is required in the khat business. This is the cogent explanation for khat trade being a risky business that involves reckless driving, accidents and other related fatalities (Cassaneli, 1986, p. 246; Goldsmith, 1988, p. 144, \& Anderson et al., 2007, p. 47).

Strict discipline at all levels of the khat value chain from the farm gate to the closing end of the network at the urban khat retailing kiosks has been a major requirement khat traders have to observe consistently. In one of my previous studies (Girma 2015, p. 196), I have thoroughly analyzed some of the stringent requirements of khat trade and how major players who wish to stay in the business need to observe the rules of the game such as adjusting to the urgency and hassle almost inherent to khat trade. The level of consistency the khat business in Ethiopia has achieved so far, as evidenced by the regular supply of khat to urban retailers with a near hundred per cent record, is the outcome of the observance of a 


\title{
Girma Negash
}

strict discipline a competitive market needs. The anecdote described in the same work mentioned above is illustrative of the centrality of discipline and commitment as applied on the khat value chain.

\begin{abstract}
A critical observer must have seen some key service providers, such as bakeries, closed in the event of occasional security problems, such as the election crisis of 2005. However, it was business as usual for most khat selling kiosks of Addis Ababa. They were "faithful" to their customers and remained operational amidst that crisis situation. Supply and distribution of khat in towns continued unabated as though the gunshots and burning tires in the streets were Christmas fireworks. It can therefore be summed up that the khat business requires the courage and determination to work not only under stressful conditions but also scary circumstances. Thus, nothing less than the vigor and the audacity of the youth can adequately satisfy its requirements (Girma 2016, p. 41).
\end{abstract}

Furthermore, equally ruinous to a business might be a long chain of intermediaries in a given trading chain. The presence and intervention of too many intermediaries in any transaction would result in a rise in the marketing cost. Ultimately, this would strain the net income of the producer (Eicher \& Baker 1982, pp. 184-185). Intermediaries in this context are a reference to all operators from the farm gate to the retail shops in towns. According to available data ${ }^{38}$ intermediaries and middlemen operating all along the trading networks that stretch out from the khat farms in Northern Sidama and Hararge, until they reach the various delivery points, are not too many. Considering the sparse distribution of the various destinations and the hundreds of retailers anxiously waiting for the arrival of their respective bundles each morning with unfailing consistency, the number of intermediaries involved is not many.

The number of intermediaries and the services they render in the trading system may not be the same all through the year. There might be some variations in the number of intermediaries needed at different levels of the business at different times. The most important and special quality of the khat trading systems under study here, may be because it is in the nature of a highly competitive market, the trading

\footnotetext{
${ }^{38}$ Group discussion (FGD) with seven young khat traders operating in Wondo Genet area, 3 December 2015; Interview with Zerfu Saqalo, 19 November 2015.
} 
systems at work appear to be self-evaluative and self-updating. Imperfections and causes of waste are treats to the smooth operation of the system, hence not tolerated. Practices that are inconsistent with the time pressure and the maximalist stance of traders, who often use available capital and resources to the last drop, are usually rectified quickly and examples of effectiveness will be emulated without delay. ${ }^{39}$

The invaluable services Kontrakters provide have reduced the number of intermediaries who might have taken a more visible part in the Sidama khat trading networks. Although the prime motive of the originators of this service was investing more and maximizing profit, ${ }^{40}$ they unwittingly contributed to the efficiency of the trade from supply to distribution. Firstly, in a number of ways, the role played by the Kontrakter is a direct response to the time pressure intrinsic to the khat business. Secondly, the emergence of the institution of the Kontrakter to perform all the aforementioned tasks from origin to delivery points has certainly discouraged the possible rise of intermediary groups.

As for the impact of "inadequate infrastructure" on the efficiency of khat trade, Ezekiel's argument (Ezekiel, 2004, p. 172) that the expansion of road transport is one among the range of factors that further invigorated the commercialization of khat and the proliferation of khat farming, is sound. The validity of this point rests upon the consideration that good roads would mean a timely supply of khat to destination towns. The renovation of the Addis-Shashamane road, completed in 2001, has remarkably transformed trade in Sidama's khat. Since then, the amount of time hitherto needed to supply Sidama's khat to major towns such as Addis Ababa, Adama, Mojo and all other towns en route, has been significantly reduced (Anderson, et al. , 2007, p. 47).

"Barriers to entry," which refers to the multiple inconveniences at the various tollgates and/or customs places, no doubt would have some degree of impact on the efficiency of the trade. The inconsistent and often unstable tax regimes, a tax collection system often marred by fraud and corruption, and an ill standardized tax rates (on khat for export and local consumption) are inherent drawbacks to the Ethiopian state to get what it is supposed to get from an on- going and practically unstoppable khat trade. By the same token, these inconsistencies and irregularities that khat trade suffers from an unhealthy tax system has lived to afflict the efficiency, and for that matter, the entire trading system at large. The inspections, the weighing,

\footnotetext{
${ }^{39}$ Interview with Zerfu and Abdulhamid

${ }^{40}$ Interview with Zärfu Säqälo
} 


\section{Girma Negash}

that are mandatory rituals at each of custom posts, take time, and the consequence is a delay in khat supply to the various towns.

\section{Conclusion}

This study has thoroughly examined the most essential features and structures of the khat trading system in Southern and Eastern Ethiopia. It attempted to fill the knowledge gap about a very important but neglected economic activity- khat tradethat best explains the political economy of the regions under study. By probing into the institutional history of khat trade in the two regions with a recognized record of a vibrant khat trading activities for over three decades, the study has found out striking commonalities, adopted and improvised through time, in both the two regions. For reasons of methodological convenience it focused on the origins and progressive evolution of some key institutions, marketing principles as applied in local contexts, rules and regulations adopted, in order to maintain efficiency, regularity, and effectiveness of the trade.

The study provided an elaborate account as how the khat marketing system operates, how the range of institutions involved are created, and the unique approaches adopted by the khat trading community for the maintenance of an efficient trading system. Meanwhile, it also identified some remarkably innovative rules and regulations locally formulated in a bid to meet the considerably strict requirements of trading with a perishable commodity. Overall, this research lays out the evidence for a thesis of relatively autonomous and decentralized system of production and marketing of cash crops in which a lot of room exists for local decision making. As such, it highlights an aspect of the history of production for market in rural Africa that has been neglected or underreported in the wider literature.

Major findings of this study demonstrate that, although decentralized and reasonably free from government intervention, the khat trading system in Eastern and Southern Ethiopia is still efficient and vibrant, operating effectively without interruption, a means of livelihood to many and, generating revenue for the government. In fact, the state collected revenue and transit taxes but made little attempt to promote or intervene in the operations of the khat market. The study revealed that trading chains, reasonably autonomous, decentralized but interlinked to one another, demonstrating a high degree of discipline and work ethic operating in a very competitive trading environment have managed to ensure the regular supply of khat to the major urban centers of central and Southern Ethiopia over the last couple of decades. 


\section{References}

Amare Getahun, \& Krikorian, A.D. (1973). Chat: coffee's rival from Harar, Ethiopia. I. botany, cultivation and use. Economic Botany, 27(4), 353-389.

Anderson, D., Beckerleg, S., Degol Hailu, \& Klien, A. (2007). The khat controversy: Stimulating the debate on drugs. Oxford, New York: Berg.

Carrier, N. (2007). Kenyan Khat: The social life of a stimulant. Leiden: Koninklijke Brill.

Carrier, N. (2006). Bundles of choice: Variety and the creation and manipulation of Kenyan khat's value. Ethnos, 71(3), 415-437.

Cassanelli, L. (1986). Qat: Changes in the production and consumption of a quasi legal commodity in North East Africa. In Arjun A. (Ed.), The social life of things: Commodities in cultural perspective (pp. 236-257). Cambridge: Cambridge University Press.

Eicher, K. C., \& Baker, C. D. (1982). Research on agricultural development in Sub-Saharan Africa: A critical survey. Michigan State University: International Development Papers.

Ezekiel Gebissa. ( 2004). Leaf of Allah: Khat and agricultural transformation in Hararge Ethiopia 1875-1991. London: James Curry.

Furubotn, E.G., \& Richter, R. (2005). Institutions and economic theory: The contribution of the new institutional economics ( $2^{\text {nd }}$ ed.). Michigan: University of Michigan Press.

Garner, M., Wagner, C., \& Kawulich, B. 2009). Teaching research methods in the social sciences. Burlington (USA): Ashgate Publishing Company.

Grunbaum, N. N. (2007). Identification of ambiguity in the case study research typology: What is a unit of analysis? Qualitative Market Research, 10(1), 78-97.

Girma Negash. (2014). Agriculture and trade in Northern Sidama since 1950: A history (PhD Dissertation). Addis Ababa University: Department of History.

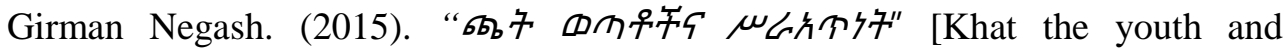

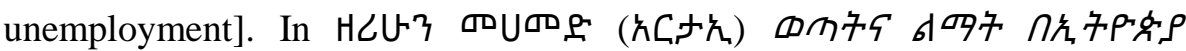
[Zerhun Mohamed, (Ed.), Youth and development in Ethiopia] (pp.189-207). Addis Ababa: Forum for Social Studies (FSS). 


\section{Girma Negash}

Girma Negash. (2016). The Ethiopian youth and the Khat quandary. Ethiopian Journal of Development Research, 38(1), 31-52.

Girma Negash. (2017). The education of children entangled in khat trade in Ethiopia: The case of two khat market centres (Monograph No. 13). Addis Ababa: Forum for Social Studies.

Goldsmith, P. (1988). The production and marketing of miraa in Kenya. In Ronald C. (Ed.), Satisfying Africa's food needs: Food production and commercialization in African agriculture (pp.121-152). London: Lynne Rienner Publishers.

Kennedy, J. G. (1987). The Flower of Paradise: The institutionalized use of the drug qat in North Yemen. Dordrecht: D. Reidel Publishing Comp.

North, C. D. (1989). Final remarks: Institutional change and economic history. Journal of Institutional and Theoretical Economics. 145, 238-245.

North, C. D. (1991), Institutions. Journal of Economic Perspectives, 5(1), 97-112.

North, C. D. (1994). Economic performance through time. The American Economic Review, 84 (3), 359-368.

Tesfaye Lemma, \& Daniel S. (2010). Market incentives, rural livelihood and a policy dilemma: Expansion of khat production in Eastern Ethiopia. In Ezekiel Gebissa (Ed.), Taking the place of food: Khat in Ethiopia (PP. 167187). Trenton (NJ): The Red Sea Press.

Varisco, D. M. (2004). The elixir of life or the devil's cud? The debate over qat (cathaedulis) in Yemeni culture. In R. Coomber, \& South, N. (Eds.), Drug use and cultural contexts: Beyond the west (pp. 101-118). London: Free Association Books.

Ward, C., \& Gatter, P. (2000). Qat in Yemen. A Document of the World Bank. 